\title{
Degradability and kinetics of fibrous particles in cattle fed diets based on corn silage and concentrates with or without addition of lipids
}

\author{
Elizabeth Fonsêca Processi ${ }^{1}$, Carlos Augusto de Alencar Fontes ${ }^{2}$, Ricardo Augusto Mendonça \\ Vieira $^{2}$, Laila Cecília Ramos Bendia ${ }^{1}$, Tiago Cunha Rocha ${ }^{3}$, Alberto Magno Fernandes ${ }^{2}$, Jéssica \\ Morais Cunha ${ }^{4}$
}

\footnotetext{
${ }^{1}$ Universidade Estadual do Norte Fluminense Darcy Ribeiro, Programa de Pós-graduação em Ciência Animal, Campos dos Goytacazes, RJ, Brazil. ${ }^{2}$ Universidade Estadual do Norte Fluminense Darcy Ribeiro, Laboratório de Zootecnia, Campos dos Goytacazes, RJ, Brazil.

${ }^{3}$ Universidade Federal da Bahia, Salvador, BA, Brazil.

${ }^{4}$ Universidade Estadual do Norte Fluminense Darcy Ribeiro, Programa de Pós-graduação em Produção Vegetal, Campos dos Goytacazes, RJ, Brazil.
}

ABSTRACT - Eight rumen-cannulated steers were assigned to two $4 \times 4$ balanced Latin squares to evaluate degradability and kinetics of fiber particles from diets based on corn silage and supplements with or without addition of lipids. Dietary treatments were: only corn silage (T1), corn silage plus concentrate with no added lipids (T2), corn silage plus concentrate with added soybean oil (T3), and corn silage plus concentrate containing ground soybean seeds (T4). Kinetics of gastrointestinal transit of fibrous particles was evaluated based on chromium-mordanted fiber. Events of rumen degradation dynamics of fibrous carbohydrates were quantified using the in situ incubation procedure. The mixed models methodology from SAS was used to fit models and the Tukey test was used to compare means. The ruminal digestibility of fiber was lower in treatments T3 and T4 and, consequently, lower proportions of potentially digestible fraction of standardized fiber and higher proportions of indigestible fraction of standardized fiber for treatments T3 and T4 compared with $\mathrm{T} 1$ and $\mathrm{T} 2$ were observed. However, there were no differences in mean retention time of the rumen, total mean retention time, mean digestion time, and rumen fill among diets. Animals from T2, T3, and T4 showed higher dry matter intake, organic matter intake, and crude protein intake rates than animals receiving $\mathrm{T} 1$ diet, but there was no effect of the addition of lipid. Treatments did not differ regarding neutral detergent fiber intake. Animals from T1 had lower crude fat intake than animals from T2, which showed lower crude fat intake than those from T3 and T4. The addition of lipid to concentrate has no effect on passage rate, digestion rate, and intake, when a good quality roughage is used.

Key Words: fiber, intake, passage rate

\section{Introduction}

The dry matter intake (DMI) determines the uptake of nutrients needed to meet maintenance and production requirements and is the most important variable in the assessment of high-roughage diets, because it is highly correlated to animal production (Noller et al., 1996).

The ability of feed to provide nutrients for animals depends on the competition between rates of degradation and passage throughout the gastrointestinal tract (Van Soest, 1994). The neutral detergent fiber (NDF) content in forages is highly correlated with intake and digestibility. According to Van Soest (1965), the forage DMI is more correlated with

Received August 21, 2015 and accepted September 2, 2016

Corresponding author: ramvieira@uenf.br

http://dx.doi.org/10.1590/S1806-92902016001200007

Copyright (C) 2016 Sociedade Brasileira de Zootecnia. This is an Open Access article distributed under the terms of the Creative Commons Attribution License (http://creativecommons.org/licenses/by/4.0/), which permits unrestricted use, distribution, and reproduction in any medium, provided the original work is properly cited.
NDF than with any other chemical component and rumen volume is affected by forage NDF (Van Soest, 1994).

Lipid supplementation in ruminant diets has a direct effect on ruminal degradability of fiber, because unsaturated fatty acids are toxic to fibrolytic bacteria (Richardson et al., 1984; Chalupa et al., 1986). The presence of lipids creates a physical barrier on the surface of fibrous particles and prevents the action of bacterial enzymes on sites of potentially digestible NDF. Lipids reduce NDF degradation in the rumen (Ferlay and Doreau, 1992), but the magnitude of depression varies with lipid chemistry and quantity, animal species, and experimental conditions (Dong et al., 1997). Therefore, the usual recommendation is that the total fat content of diet should not exceed $50 \mathrm{~g} / \mathrm{kg}$ of the feed dry matter (DM) to avoid depressions on intake and NDF digestibility, which, in its turn, would reduce the benefit of a larger energy density in the diet by the addition of lipid (Palmquist and Jenkins, 1980). Later, Palmquist (1989) and Jenkins (1993) suggested the $70 \mathrm{~g} / \mathrm{kg}$ threshold, above which lipids reduce both DMI and NDF digestibility. 
In light of the above-mentioned facts, we expect that the reduced digestibility of the fiber fraction of the diet caused by lipids may be accompanied by decreases in digestibility of other nutrients too, because fatty acids reduce the $\mathrm{pH}$ of the rumen and, consequently, alter the ruminal microbiota, which compromises the energy availability of the diet. Furthermore, lipids may limit DMI by increasing the retention time of ingested fibrous particles in the rumen because of a reduced passage rate through the gastrointestinal tract.

We aimed to estimate intake and the kinetic parameters of degradation and passage of the NDF of diets based on corn silage and concentrate supplements with or without addition of lipids.

\section{Material and Methods}

Eight rumen-cannulated European-Zebu crossbred steers with average live weight of $281.3 \pm 28.7 \mathrm{~kg}$ and $401.1 \pm 20.5 \mathrm{~kg}$ at the beginning and end of the experiment were used. The animals were divided into two simultaneous $4 \times 4$ balanced Latin squares. The animals with permanent rumen cannulas were maintained according to the protocol number 207 (maintenance and care of animals with permanent rumen cannulas) approved by the Institutional Ethics Committee for Animal Use. The animals were dewormed and housed in individual pens provided with feeder and water drinker, where they were adapted to facilities, diets, and experimental conditions before the beginning of the experiment.

We used four experimental diets (Tables 1 and 2) to compare corn silage (T1), corn silage and a conventional concentrate without addition of lipids (T2), corn silage and concentrate containing $50 \mathrm{~g} / \mathrm{kg}$ DM of lipid by addition of soybean oil (T3), and corn silage and concentrate containing $50 \mathrm{~g} / \mathrm{kg}$ DM of lipid by addition of cracked soybean seeds (T4).

The experiment lasted 112 days and consisted of four periods of 28 days, 12 days for adaptation of animals to treatments and the remaining 16 days for sample collection.

Table 1 - Proportions of ingredients in the experimental diets

\begin{tabular}{lcccc}
\hline \multirow{2}{*}{ Ingredient } & \multicolumn{4}{c}{ Treatment $(\mathrm{kg} / \mathrm{t}$ metric dry matter $)$} \\
\cline { 2 - 5 } & $\mathrm{T} 1$ & $\mathrm{~T} 2$ & $\mathrm{~T} 3$ & $\mathrm{~T} 4$ \\
\hline Corn silage & 100.00 & 70.00 & 70.00 & 70.00 \\
Soybean seeds & - & - & - & 16.43 \\
Corn grains & - & 16.88 & 13.12 & 13.02 \\
Soybean oil & - & - & 3.10 & - \\
Limestone & - & 0.59 & 0.57 & 0.55 \\
Soybean meal & - & 12.53 & 13.21 & - \\
\hline
\end{tabular}

The animals were fed at 8.00 and $16.00 \mathrm{~h}$ daily and orts were kept on $5 \%$. Intake was measured daily by the difference between the amounts of feed offered and orts. The feed supplied was sampled and orts were weighed before the morning meal. An amount of $10 \%$ of orts (fresh basis) was sampled daily to form composite samples for each animal $\times$ period interaction.

Samples of corn silage, concentrates, and orts were dried in a forced-air oven at $55^{\circ} \mathrm{C}$ for $72 \mathrm{~h}$ and grounded to $1 \mathrm{~mm}$ in a Wiley mill for further analyses, as follows: dry matter (AOAC method 967.03; AOAC, 1990), crude ash (CA, AOAC method 942.05; AOAC, 1990), and organic matter (OM) by difference. To complete the standard chemical analysis, we determined the contents of crude protein $(\mathrm{CP}$, AOAC method 2001.11; Thiex et al., 2002), crude fat (CF, AOAC method 2003.06; Thiex et al., 2003), and neutral detergent fiber (aNDFom) estimated according to AOAC method 2002.04 (Mertens, 2002), but on Berzelius flasks with spouts.

The daily intakes of DM, OM, CA, CP, CF, and aNDFom were calculated considering the quantities $(\mathrm{kg})$ of the respective nutrients in the offered matter and in the orts.

To evaluate the $\mathrm{pH}$ of the rumen fluid, on the $23 \mathrm{rd}$ day of each experimental period, the direct samples were collected at the liquid-raft interface of the rumen before and two, four, six, and eight hours after the morning meal. Afterwards, the samples of rumen fluid were filtered through three layers of cheesecloth and the $\mathrm{pH}$ was measured by digital $\mathrm{pH}$ meter.

From the 24th to 28th day of each experimental period, the transit of fibrous particles was evaluated throughout the gastrointestinal tract based on the supply of a pulse dose of mordant chromium as an external marker (Udén et al., 1980; Ellis et al., 1994). Samples of the forage fed at each period were taken to prepare the chromium-mordanted fiber. At $8.00 \mathrm{~h}$ on the 24th day, $100 \mathrm{~g}$ of mordanted fiber were placed in the rumen of the animals. Fecal samples were collected from the rectum at $0,3,6,9,12,15,18$, $21,24,28,32,36,40,44,48,54,60,72,84,96,108$, and $120 \mathrm{~h}$ after marker administration. The samples were dried

Table 2 - Chemical composition of experimental diets (silage + concentrate)

\begin{tabular}{lcccc}
\hline \multirow{2}{*}{ Composition } & \multicolumn{4}{c}{ Treatment $(\mathrm{g} / \mathrm{kg}$ dry matter) } \\
\cline { 2 - 5 } & $\mathrm{T} 1$ & $\mathrm{~T} 2$ & $\mathrm{~T} 3$ & $\mathrm{~T} 4$ \\
\hline Dry matter $(\mathrm{g} / \mathrm{kg}$ of diet) & 316.5 & 390.4 & 389.6 & 385.0 \\
Organic matter & 917.4 & 930.5 & 927.2 & 930.0 \\
Crude protein & 54.0 & 116.5 & 114.0 & 113.0 \\
Ether extract & 15.2 & 18.4 & 47.8 & 48.4 \\
Crude ash & 82.6 & 69.5 & 72.94 & 70.0 \\
Neutral detergent fiber & 521.1 & 390.4 & 404.4 & 383.9 \\
\hline
\end{tabular}


in a forced-air oven $\left(55^{\circ} \mathrm{C}\right.$ for $\left.72 \mathrm{~h}\right)$ and processed in a Wiley mill (1-mm sieve). Chromium levels were measured using the methodology described by Campbell and Plank (1992) with modifications, in which samples were wetdigested using nitric acid and hydrogen peroxide for further inductively coupled plasma analysis.

For the estimation of passage kinetics, an in situ incubation procedure was carried out to quantify the dynamic events of rumen degradation of fibrous carbohydrates. For that, the silage samples were pre-dried in a forcedventilation oven at $55^{\circ} \mathrm{C}$ and processed in a Wiley mill $(5 \mathrm{~mm})$. The material was weighed into tared nylon bags, according to a DM to bag surface ratio equal to $20 \mathrm{mg} / \mathrm{cm}^{2}$ (Nocek, 1988). Nylon bags were introduced directly into the rumen of the animals. Incubation times evaluated were: $0,3,6,9,12,18,24,30,36,48,72,96$, and $120 \mathrm{~h}$. After removal, bags were rinsed thoroughly with tap water until the wash water was clear. In sequence, bags were dried in a forced-ventilation oven at $55^{\circ} \mathrm{C}$ for $72 \mathrm{~h}$ and the aNDFom content was determined by the AOAC method 2002.04 (Mertens, 2002) on Berzelius flasks without spouts.

A Gaussian noise model was used to describe the kinetics of a marker concentration $(\mathrm{Cr})$ in the feces, as follows (Matis, 1972; Pond et al., 1988):

$$
\begin{aligned}
& C(t)=\left\{\begin{array}{cc}
\epsilon_{t} & \text { for } t<\tau\left(t^{*}<0\right) \\
C \dot{p}_{0\left(t^{*}\right)+\epsilon_{t}} & \text { for } t \geq \tau\left(t^{*} \geq 0\right)
\end{array}\right. \\
& \dot{p}_{0}=(\lambda t)^{N-1} \lambda \exp (-\lambda t) /(N-1) !
\end{aligned}
$$

in which $\dot{p}_{0}$ is the probability density function; $\lambda$ is the asymptotic value of the time dependent passage rate; and $\mathrm{N}$ is a positive integer whose values are valid for $\mathrm{N} \geq 2$. The parameters of this model provide estimates to explain the dynamics of fibrous particles through the gastrointestinal tract of ruminants (Matis et al., 1989; Ellis et al., 2000).

The $k_{p}$ values were estimated according to Pond et al. (1988):

$$
\bar{k}_{p}=\lambda * F
$$

in which

$\mathrm{F}=0.59635$ when $N=2$;

$\mathrm{F}=0.47454$ when $N=3$;

$\mathrm{F}=0.40856$ when $N=4$;

$\mathrm{F}=0.36527$ when $N=5$;

$\mathrm{F}=0.33929$ when $N=6$.

The mean rumen retention time (MRRT) and mean total retention time (MTRT) of particles were estimated according Pond et al. (1988):

$M R R T=N / \lambda$

Eq. (04)
$\operatorname{MTRT}=N / \lambda+\tau$

Eq. (05)

The interpretation of fiber profiles were made employing the decreasing logistic model proposed by Vieira et al. (2008a):

$R(t)=\tilde{A}\left\{\theta_{d}^{\mathrm{H}_{a}} \exp \left(-k_{d} T\right)+v \exp \left(-\lambda_{a} T\right) \times \sum_{\eta=0}^{\mathrm{H}_{a}-1}\left[\left(1-\delta_{a}^{\mathrm{H}_{a}-\eta}\right)\left(\lambda_{a} t\right)^{\eta} / \eta !\right]\right\}+U+e$

Eq. (06),

in which $R(t)$, expressed as $\mathrm{g} / \mathrm{kg} \mathrm{DM}$, is the aNDFom residue after incubation for a given time, $\mathrm{t}$ (hours); $\tilde{\mathrm{A}}$ is the unavailable form of $A_{N D F}$ fraction ( $\left./ \mathrm{kg} \mathrm{DM}\right) ; A_{N D F}$ is the potentially digestible fiber fraction available to be digested by rumen microorganisms $(\mathrm{g} / \mathrm{kg} \mathrm{DM}) ; k_{d}$ is the degradation rate of $\mathrm{A}_{\mathrm{NDF}}$; and $\mathrm{U}$ is the indigestible fraction of aNDFom. Fractions A and U were normalized (Waldo et al., 1972) and named as An and Un. If the nature of the substrate allowed almost immediate digestion, it was assumed that $N=0$ and $\lambda_{\alpha} \rightarrow \infty$. In this case, $R(\mathrm{t})$ was converged to a decreasing exponential model with no "lag" (Vieira et al., 2008a).

The true rumen digestibility of fiber was determined as proposed by Ellis (1978) and Ellis et al. (1994), using the mathematical model described below:

$D_{N D F}=k_{d} /\left(k_{d}+\bar{k}_{p}\right)$

Eq. (07),

in which $D_{N D F}$ is the true ruminal digestibility coefficient of fiber; $k_{d}$ is the degradation rate of potentially degradable fraction; and $\bar{k}_{p}$ is the average estimated escape rate of rumen particles.

The rumen fill effect of fiber was estimated using the model of Ellis (1978) and Ellis et al. (1994):

$R F=F\left(A /\left(k_{d}+\bar{k}_{p}\right)+U / \bar{k}_{p}\right)$

The mean digestion time was estimated according to Vieira et al. (2008a), whose principle was described initially by Matis et al. (1989):

If $N=0$, then $M D T=1 / k_{d}$; otherwise, $M D T=N_{a} / \lambda_{a}+1 / k_{d}$,

Eq. (09)

The parameters of the degradation and passage models of fibrous particles were estimated using the NLIN procedure of SAS (Statistical Analysis System, version 9.0). Both algorithms, Newton and Marquardt were used. The preferred algorithm was Newton, but when the correlations between the parameter estimates were high, the Marquardt algorithm was preferred (Vieira et al., 2008a; 2012). In some cases, the estimates of degradation parameters were obtained according to the procedures of robust regression to reduce the effect of outliers (Beaton and Tukey, 1974). 
The selection of the order of time dependency $(\mathrm{N})$ and, therefore, the best model to explain the dynamics of particles was evaluated by calculating the Akaike information criterion (Akaike, 1974) corrected for finite samples $\left(\mathrm{AICc}_{\mathrm{h}}\right)$ (Sugiura, 1978). The $\mathrm{AICc}_{\mathrm{h}}$ was calculated from the sum of squares of residues from the estimated parameters, including the residual variance and the sample size. The values of $\mathrm{AICc}_{\mathrm{h}}$, model probability, and evidence ratio for each $\mathrm{N}$ version were calculated using the equations described by Vieira et al. (2008a,b; 2012).

In the statistical analysis of the parameter estimates of the particle dynamics and nutrient intake, the following statistical model (Tempelman, 2004) was used:

$y_{i j k}=\mu+\alpha_{i}+\beta_{j}+a_{k}+\alpha \beta_{i j}+e_{i j k}$

Eq. (10), in which $y_{i j k}$ is the observation in the $k$-th animal receiving treatment $i$ in $j$-th period; $\alpha_{i}$ represents the effect of the $i$-th treatment, for $i=1,2,3$, and $4 ; \beta_{j}$ represents the effect of the $j$-th period, for $j=1,2,3$, and 4 ; and $a_{k}$ represents the effect of the $k$-th animal, $\forall k=1,2,3,4,5,6,7$, and 8 with variance component $\sigma^{2}$.

The statistical analysis of intake data was performed as follows:

$y_{i j k l m}=\mu+\alpha_{i}+P_{j}+A_{k}+Q_{l}+D_{m j}+e_{i j k l m} \quad$ Eq. (11), in which $y_{i j k l m}$ is the observation on day $m$, in Latin square $l$, in the animal $k$, in the period $j$, in certain treatment $i ; \alpha_{i}$ represents the effect of the $i$-th treatment, for $i=1,2,3$, and $4 ; P_{j}$ represents the effect of the $j$-th period, for $j=1$, 2,3 , and $4 ; \mathrm{A}_{k}$ represents the effect of the animal $k$-th, for $\mathrm{k}=1,2,3,4,5,6,7$, and $8 ; Q_{l}$ represents the effect of the $k$-th Latin square, for $l=1$ and $2 ; D_{m j}$ represents the effect of day $m$, within the period $j, m=1,2,3,4$ and 5; and $e_{i j k l m}$ represents the random error with zero mean and variance $\sigma^{2}$. The treatment effect was considered fixed and the effects of Latin square, period, animal, and day were considered random.

The statistical model was fitted by the PROC MIXED procedure of SAS (Statistical Analysis System, version 9.0) with maximum likelihood as the estimating method and variance-covariance matrices arranged as compound symmetry, random auto regressive correlations, variance components, and unstructured variance-covariance without restrictions (Littell et al. 1998, 2006). Once the AICc (Akaike information criterion) is one of the outputs of SAS, these different variance-covariance structures were evaluated based on the information criteria described by equations as suggested by Vieira et al. (2008a,b; 2012). The protected Tukey test was used to detect differences between treatments (Littel et al., 2006).

\section{Results and Discussion}

The structure of the variance-covariance arranged as variance components was the best model to estimate the parameters of passage rate and degradability of the fibrous fractions in the gastrointestinal tract. For intake of DM, $\mathrm{OM}, \mathrm{CA}, \mathrm{CP}, \mathrm{CF}$, and aNDFom, the best structure was the random auto regressive correlation.

The effects of period and treatment and period interaction for all variables analyzed by fitting Eq.(10) were nonsignificant; however, there were significant treatment effects for the variables $\mathrm{D}_{\mathrm{NDF}}$ standardized potentially digestible fiber (Bn), and standardized indigestible fiber (Un) (Table 3).

Table 3 - P-values of the model effects as Latin square (LS), treatments (TREAT), period (PER), and interactions (LS $\times$ TREAT and PER $\times$ TREAT) for the analyzed variables

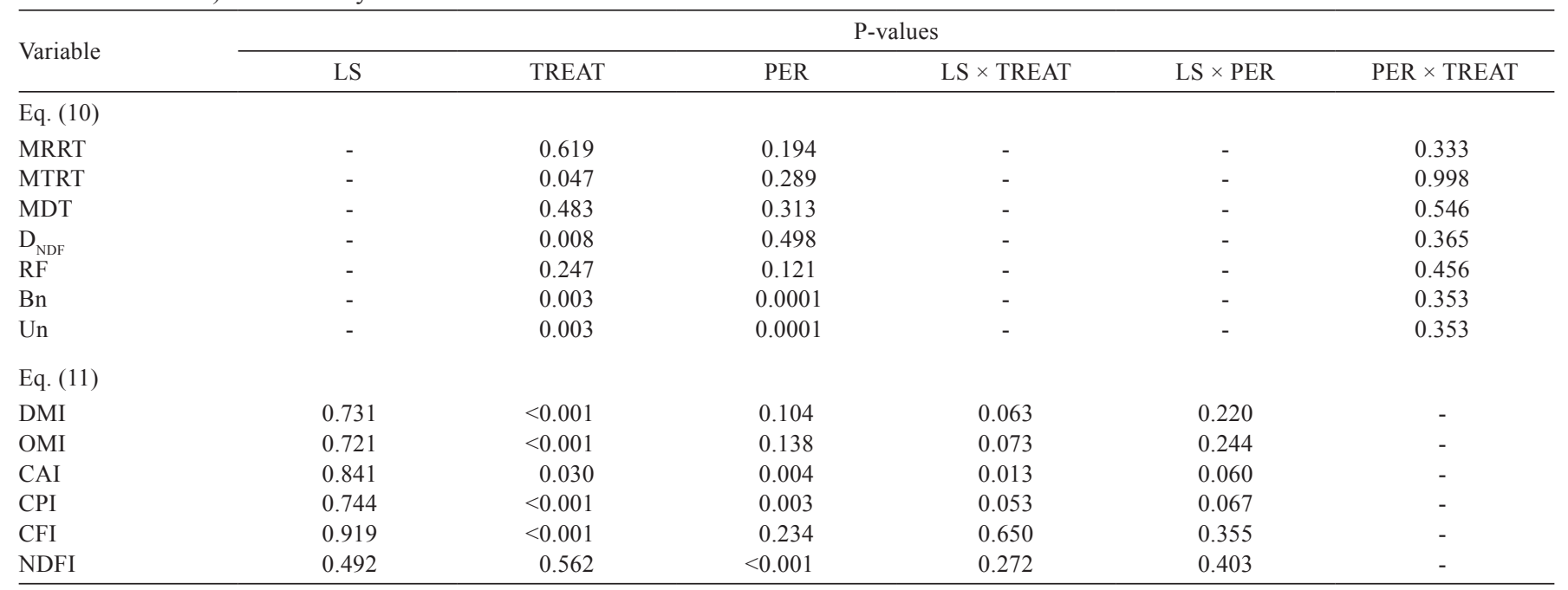

MRRT - mean ruminal retention time; MTRT - mean total retention time; MDT - mean digestion time; D potentially digestible standardized fiber; Un - indigestible standardized fiber; DMI - dry matter intake; OMI - organic matter intake; CAI - crude ash intake; CPI - crude protein intake; CFI - crude fat intake; and NDFI - neutral detergent fiber intake. 
The $\mathrm{D}_{\mathrm{NDF}}$ was lower for treatments containing concentrate with the addition of lipid (T3 and T4) (Table 4). Therefore, there were also lower proportions of $\mathrm{Bn}$ and higher proportions of Un for those treatments with addition of lipids. All treatments consisting of corn silage and corn silage and concentrate with no addition of lipids presented the opposite behavior (Table 2).

Corn silage is the most used roughage in intensive production systems and the reduction of its fiber digestibility decreases the availability of digestible and metabolizable energy of this forage source (Jardim et al., 2013; 2015), which implies a reduction in the daily weight gain of the animal. Nevertheless, we did not consider this variable, because short periods of evaluation hamper inferences on weight gain (Eaton et al., 1959), as those short periods of the Latin square design.

The lipids added to the diets of ruminants can modify rumen fermentation by physical and chemical mechanisms. Polyunsaturated fatty acids are toxic to some ruminal microorganisms, particularly protozoans, methanogenic, and fibrolytic bacteria (Palmquist and Mattos, 2006). Added lipids can also coat food particles, which limits the particle colonization by microorganisms, a necessary step for hydrolysis to occur by the digestive actions of bacterial enzymes on plant tissues (Palmquist and Mattos, 2006). As a result of these two mechanisms, which agree with the findings of our study, there is a reduction on the digestibility of the fibrous fraction as a consequence of an increase in the indigestible fraction (Un) and a reduction of the potentially digestible fraction $(\mathrm{Bn})$ with the addition of lipid.

The reduction of fiber digestibility caused by lipids may be accompanied by decreases in the digestibility of other nutrients, which compromises the energy value of feed, and may limit the DMI for promoting greater retention time of the fiber in the rumen and lower passage rate through the gastrointestinal tract. However, in this study,

Table 4 - Least square means and standard errors of transit and parameters of degradation dynamics of corn silage fiber in cattle

\begin{tabular}{lcccc}
\hline \multirow{2}{*}{ Parameter } & \multicolumn{4}{c}{ Treatment } \\
\cline { 2 - 5 } & $\mathrm{T} 1$ & $\mathrm{~T} 2$ & $\mathrm{~T} 3$ & $\mathrm{~T} 4$ \\
\hline MRRT & $45.92 \pm 2.71$ & $41.33 \pm 2.71$ & $44.91 \pm 2.71$ & $42.43 \pm 2.71$ \\
MTRT & $58.74 \pm 1.98$ & $51.64 \pm 1.98$ & $54.37 \pm 1.98$ & $54.38 \pm 1.98$ \\
MDT & $35.21 \pm 7.72$ & $30.69 \pm 7.72$ & $40.23 \pm 7.72$ & $28.65 \pm 7.72$ \\
$\mathrm{D}_{\text {NDF }}$ & $0.37 \mathrm{a} \pm 0.02$ & $0.34 \mathrm{a} \pm 0.02$ & $0.25 \mathrm{~b} \pm 0.02$ & $0.26 \mathrm{~b} \pm 0.02$ \\
RF & $19.99 \pm 1.74$ & $18.25 \pm 1.74$ & $23.58 \pm 1.74$ & $21.13 \pm 1.74$ \\
Bn & $0.67 \mathrm{a} \pm 0.03$ & $0.68 \mathrm{a} \pm 0.03$ & $0.56 \mathrm{~b} \pm 0.03$ & $0.51 \mathrm{~b} \pm 0.03$ \\
Un & $0.33 \mathrm{a} \pm 0.03$ & $0.32 \mathrm{a} \pm 0.03$ & $0.45 \mathrm{~b} \pm 0.03$ & $0.49 \mathrm{~b} \pm 0.03$ \\
\hline
\end{tabular}

MRRT - mean ruminal retention time (h); MTRT - mean total retention time (h); MDT - mean digestion time (h); $\mathrm{D}_{\mathrm{NDF}}$ - ruminal coefficient of fiber digestibility; RF rumen fill (h); Bn - potentially digestible standardized fiber; and Un - indigestible fraction of standardized fiber.

Means followed by different letters in the rows differ $(\mathrm{P}<0.01)$ by Tukey test. no differences were found in MRRT $(\mathrm{P}=0.533)$, MTRT $(\mathrm{P}=0.998)$, mean digestion time $(\mathrm{MDT} ; \mathrm{P}=0.168)$, and rumen fill (RF; $\mathrm{P}=0.345)$ among the diets irrespective to the presence of lipids. Despite the reduction in $\mathrm{D}_{\mathrm{NDF}}$ and $\mathrm{Bn}$ and the Un increase as a result of the addition of lipid to the diet, no effects of the addition of lipid on RF and MDT were observed. According to Mertens (1987), rumen fill asymptotes at a fiber intake rate, on average, of $12 \mathrm{~g} / \mathrm{kg}$ of live weight per day, which physically constrains intake. In this study, no animal ate fiber at an intake rate greater than $10 \mathrm{~g} / \mathrm{kg}$ of live weight per day. This means that the regulatory mechanisms constraining intake might have operated at the physiological level. Consequently, there was no effect of the addition of lipid on both fiber MRRT and MTRT. This can be explained by the good quality of the silage given to the animals (Table 2) and by the fact that the degradability of fiber presented no detectable lag because $\lambda_{\alpha} \rightarrow \infty$, which means that the nature of the substrate allows, for all practical purposes, its immediate digestion (Vieira et al., 2008a). Whenever a silage of the reported quality reaches the rumen, no time for substrate preparation is necessary for microbial digestion.

The physical distension of the rumen has been accepted as the main factor limiting the intake of forages and diets with high fiber content (Baile and Forbes, 1974; Allen, 1996; Allen and Bradford, 2012). Intake rates varies inversely with the filling capacity of the roughage, which is represented by the mass of fiber present in the rumen (Conrad et al., 1964; Mertens, 1987; Vieira et al., 2008b; Regadas Filho et al., 2014a,b). In this study, the diets containing lipids showed no ruminal distension effect $(\mathrm{P}=0.087)$, which is demonstrated by the constancy of fiber intake, regardless of the treatment (Table 5).

The intake of DM, OM, CA, CP, and aNDFom of the animals were not affected $(\mathrm{P}=0.463, \mathrm{P}=0.450, \mathrm{P}=0.690$, $\mathrm{P}=0.309$, and $\mathrm{P}=0.830$ ) by the addition of lipid. Probably,

Table 5 - Means and standard errors for nutrient intake of steers fed corn silage and concentrate supplements with or without addition of lipids

\begin{tabular}{lcccc}
\hline \multirow{2}{*}{ Variable } & \multicolumn{4}{c}{ Treatment } \\
\cline { 2 - 5 } & $\mathrm{T} 1$ & $\mathrm{~T} 2$ & $\mathrm{~T} 3$ & $\mathrm{~T} 4$ \\
\hline DMI (kg) & $5.99 \mathrm{~b} \pm 0.28$ & $7.87 \mathrm{a} \pm 0.28$ & $7.57 \mathrm{a} \pm 0.28$ & $7.50 \mathrm{a} \pm 0.28$ \\
OMI (kg) & $5.50 \mathrm{~b} \pm 0.26$ & $7.32 \mathrm{a} \pm 0.26$ & $7.03 \mathrm{a} \pm 0.26$ & $6.98 \mathrm{a} \pm 0.26$ \\
CAI (kg) & $0.50 \mathrm{a} \pm 0.022$ & $0.55 \mathrm{~b} \pm 0.02$ & $0.54 \mathrm{ab} \pm 0.02$ & $0.52 \mathrm{ab} \pm 0.02$ \\
CPI (kg) & $0.34 \mathrm{~b} \pm 0.03$ & $0.92 \mathrm{a} \pm 0.03$ & $0.89 \mathrm{a} \pm 0.03$ & $0.86 \mathrm{a} \pm 0.03$ \\
CFI (kg) & $0.09 \mathrm{c} \pm 0.01$ & $0.14 \mathrm{~b} \pm 0.01$ & $0.38 \mathrm{a} \pm 0.01$ & $0.36 \mathrm{a} \pm 0.01$ \\
NDFI (kg) & $3.22 \pm 0.13$ & $3.12 \pm 0.13$ & $3.10 \pm 0.13$ & $3.05 \pm 0.13$ \\
\hline
\end{tabular}

DMI - dry matter intake; OMI - organic matter intake; CAI - crude ash intake; CPI - crude protein intake; CFI - crude fat intake; and NDFI - neutral detergent fiber intake.

Means followed by different letters in the rows $\operatorname{differ}(\mathrm{P}<0.01)$ by Tukey test. 
the level of addition of lipid used was not high enough to limit intake, because this reduction is usually a consequence of reduction of food passage rate through the rumen, a variable that was not affected by the addition of lipid either $(\mathrm{P}=0.498)$. The reduction of ruminal digestibility of fiber can also reduce intake, especially of aNDFom whenever fill is the limiting factor (Conrad et al., 1964; Ellis, 1978; Allison, 1985; Allen, 1996). In this study, as previously shown, a reduction of MRRT was not observed with the addition of lipid; however, the digestibility of fiber was reduced by the addition of lipid, but the reduced digestibility did not affect the aNDFom intake. The digestibility depression did not affect the fiber (aNDFom) intake rate because digestion is the result between two competing forces (digestion and passage). Therefore, compensating mechanisms may operate as well, e.g. at higher intakes, there is less time for digestion and by far animals could hold a larger digesta load of fiber that was not provided by any of the formulated diets.

According to Osbourn et al. (1974), in adult animals, the energy intake is limited by animal demand and not by rumen fill, when the NDF content of diet is below 50 to $60 \%$. However, in this study the use of concentrates interfered $(\mathrm{P}<0.001)$ in intakes of $\mathrm{DM}, \mathrm{OM}, \mathrm{CP}$, and $\mathrm{CF}$. The animals that received concentrates (T2, T3, and T4) had higher intake rates of these nutrients than animals fed only corn silage (T1).

The non-fibrous carbohydrates provided by the concentrates may reduce ruminal $\mathrm{pH}$ (Tamminga et al., 1990) and fiber digestion (Russell, 2002). The lower digestibility of the fiber may derive from the preference of microorganisms for more rapidly fermentable carbohydrates (Hoover, 1986; Russell, 2002) and from the adverse effects of a reduced $\mathrm{pH}$ on fibrolytic microorganisms (Russell, 2002). However, in this study, the addition of concentrates did not reduce fiber digestibility and ruminal $\mathrm{pH}$ (Figure 1),

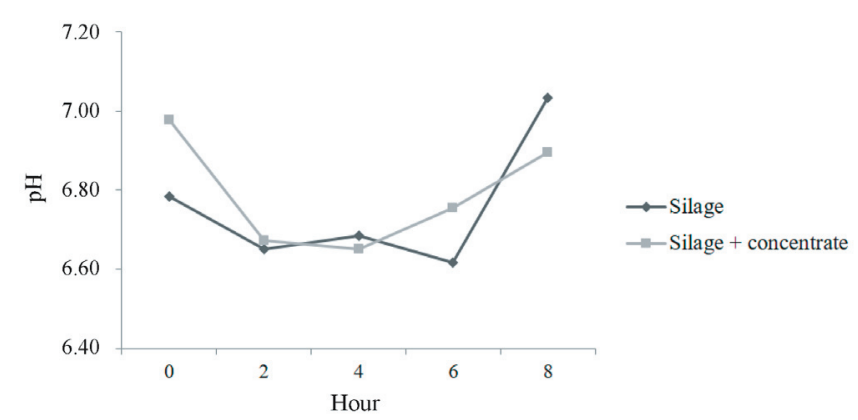

Figure 1 - Ruminal $\mathrm{pH}$ of cattle receiving corn silage and corn silage with concentrate. probably due to the moderate level of concentrate addition $(30 \%)$.

In this study, diets containing concentrates had greater DM, OM, CP, and CF contents (Table 2) than the sole corn silage diet. Animals fed sole corn silage presented the lowest intake rates of these nutrients $(\mathrm{P}<0.001, \mathrm{P}<0.001, \mathrm{P}<0.001$, $\mathrm{P}=0.334)$. The CF content of diet may also explain the lower $\mathrm{CF}$ intake rates observed for $\mathrm{T} 1$, if compared with $\mathrm{T} 2(\mathrm{P}=0.403)$, and for $\mathrm{T} 2$, if compared with treatments T3 and $\mathrm{T} 4(\mathrm{P}=0.830)$. Regarding ash intake rate, differences were observed $(\mathrm{P}<0.001)$ between treatments, but without a clear trend, probably due to contamination of the orts with minerals from the concrete-made trough.

\section{Conclusions}

The addition of lipid reduces fiber digestibility and both increase and decrease the in situ estimated amounts of indigestible and potentially digestible fractions, respectively. Nevertheless, the kinetic-related estimates such as mean retention times, mean digestion rates, and measurable intake rates appear insensitive to the addition of lipid for growing steers fed corn silage and concentrates. Therefore, the use of lipids in concentrates for cattle is an interesting strategy because it increases the energy concentration of the diet without reducing the passage rate, fiber degradability, and intake rates of nutrients when the roughage provided is of good quality.

\section{Acknowledgments}

To Coordenação de Aperfeiçoamento de Pessoal de Nível Superior - CAPES for granting the doctoral scholarship.

\section{References}

Allen, M. S. 1996. Physical constraints on voluntary intake of forages by ruminants. Journal of Animal Science 74:3063-3075.

Allen, M. S. and Bradford, B. J. 2012. Control of food intake by metabolism of fuels: a comparison across species. Proceedings of the Nutrition Society 71:401-409.

Allison, C. D. 1985. Factors affecting forage intake by range ruminants: a review. Journal of Range Management 38:4.

Akaike, H. 1974. A new look at the statistical model identification. IEEE Transactions on Automatic Control 19:716-723.

AOAC - Association of Official Analytical Chemistry. 1990. Official methods of analysis. 15th ed. AOAC International, Arlington, VA.

Baile, C. A. and Forbes, J. M. 1974. Control of feed intake and regulation of energy balance in ruminants. Physiological Reviews $54: 160-214$. 
Beaton, A. E. and Tukey, J. W. 1974. The fitting of power series, meaning polynomials, illustrated on band spectroscopic data. Technometrics 16:147-185.

Campbell, C. R. and Plank, C. O. 1992. Sample preparation. Organic Matter Destruction-Wet Ashing. In: Pant analysis reference procedures for the southern region of the United States.

Chalupa, W.; Vecchiarelli, B.; Elser, A. E.; Kronfeld, D. S.; Sklan, D. and Palmquist, D. L. 1986. Ruminal fermentation in vivo as influenced by long-chain fatty acids. Journal of Dairy Science 69:5:1293-1301.

Conrad, H. R.; Hibbs, J. W. and Pratt, A. D. 1964. Regulation of feed intake in dairy cows. I. Change in importance of physical + physiological factors with increasing digestibility. Journal of Dairy Science 47:54-62.

Dong, Y.; Bae, H. D.; McAllister, T. A.; Mathison, G. W. and Cheng, K-J. 1997. Lipid-induced depression of methane production and digestibility in the artificial rumen system (RUSITEC). Canadian Journal of Animal Science 77:269-278.

Eaton, H. D.; Gosslee, D. G. and Lucas, H. L. 1959. Effect of duration of experiment of experimental errors in calf nutrition growth studies. Journal of Dairy Science 42:1398-1400.

Ellis, W. C. 1978. Determinants of grazed forage intake and digestibility. Journal of Dairy Science 61:1828-1840.

Ellis, W. C.; Matis, J. H.; Hill, T. H. and Murphy, M. R. 1994. Methodology for estimating digestion and passage kinetics of forages. p.682-756. In: Forage quality, evaluation and utilization. Fahey, Jr., G. C., ed. American Society of Agronomy, MA, USA.

Ellis, W. C.; Poppi, D. and Matis, J. H. 2000. Feed intake in ruminantes: kinetic aspects. p.335-363. In: Farm animal metabolism and nutrition. D’Mello, J. P. F., ed. CAB International, Wallingford, OX.

Ferlay, A. and Doreau, M. 1992. Influence of method of administration of rapeseed oil in dairy cows. 1. Digestion of nonlipid components. Journal of Dairy Science 75:3020-3027.

Hoover, W. H. 1986. Chemical factors involved in ruminal fiber digestion. Journal of Animal Science 69:2755.

Jardim, J. G.; Vieira, R. A. M.; Fernandes, A. M.; Araujo, R. P.; Glória, L. S.; Rohem Júnior, N. M.; Rocha, N. S. and Abreu, M. L. C. 2013. Application of a nonlinear optimization tool to balance diets with constant metabolizability. Livestock Science 158:106-117.

Jardim, J. G.; Vieira, R. A. M.; Fernandes, A. M.; Araujo, R. P.; Glória, L. S.; Rohem Júnior, N. M.; Rocha, N. S. and Abreu, M. L. C. 2015. Corrigendum to "Application of nonlinear optimization tool to balance diets with constant metabolizability". Livestock Science 173:119-120.

Jenkins, T. C. 1993. Lipid metabolism in the rumen. Journal of Dairy Science 76:3851-3868.

Littell, R. C.; Henry, P. R. and Ammerman, C. B. 1998. Statistical analysis of repeated measures data using SAS procedures. Journal of Animal Science 76:1216-1231.

Littell, R. C.; Miliken, G. A.; Stroup, W. W.; Wolfinger, R. D. and Schabenberger, O. 2006. SAS ${ }^{\circledR}$ for mixed models. 2nd ed. Cary, USA.

Matis, J. H. 1972. Gamma time-dependency in Blaxter's compartmental model. Biometrics 28:597-602.

Matis, J. H.; Wehrly, T. E. and Ellis, W. C. 1989. Some generalized stochastic compartment models for digesta flow. Biometrics 45:703-720.

Mertens, D. R. 1987. Predicting intake and digestibility using mathematical models of ruminal function. Journal of Animal Science 64:1548-1538.

Mertens, D. R. 2002. Gravimetric determination of amylase-treated neutral detergent fiber in feeds with refluxing in beakers or crucibles: collaborative study. Journal of Official Analytical Chemists 85:1217-1240.

Nocek, J. E. 1988. In situ and other methods to estimate ruminal protein and energy digestibility: a review. Journal of Dairy Science 71:2051-2069.

Noller, C. H.; Nascimento Júnior, D. and Queiroz, D. S. 1996. Exigências nutricionais de animais em pastejo. p.319-352. In: Anais do Simpósio de Manejo de Pastagens, Piracicaba.

Osbourn, D. F.; Terry, R. A.; Outen, G. E. and Cammell, S. B. 1974. The significance of a determination of cell walls as the rational basis for nutritive evaluation of forages. p.374-380. In: Proceedings of the 12th International Grassland Congress, Moscou.

Palmquist, D. L. and Jenkins, T. C. 1980. Fat in lactation rations: review. Journal of Dairy Science 63:1:1.

Palmquist, D. L. 1989. Suplementação de lipídio para vacas em lactação. p.11-25. In: Anais do Simpósio sobre Nutrição de Ruminantes. Fundação de Estudos Agrários "Luiz de Queiroz", Piracicaba.

Palmquist, D. L. and Mattos, W. R. S. 2006. Metabolismo de lipídeos. p.287-310. In: Nutrição de ruminantes. Berchielli, T. T., ed. FUNEP, Jaboticabal.

Pond, K. R.; Ellis, W. C.; Ferreiro, H. M. and Sutton, J. D. 1988. Compartment models for estimating attributes of digesta flow in cattle. British Journal of Nutrition 60:571-595.

Regadas Filho, J. G. L.; Tedeschi, L. O.; Cannas, A.; Vieira, R. A. M. and Rodrigues, M. T. 2014a. Using the Small Ruminant Nutrition System to develop and evaluate an alternative approach to estimating the dry matter intake of goats when accounting for ruminal fiber stratification. Journal of Dairy Science 97:7185-7196.

Regadas Filho, J. G. L.; Tedeschi, L. O.; Vieira, R.A.M. and Rodrigues, M.T. 2014b. Assessment of the heterogeneous ruminal fiber pool and development of a mathematical approach for predicting the mean retention time of feeds in goats. Journal of Animal Science 92:1099-1109.

Richardson, L. F.; Raun, A. P.; Potter, E. L.; Cooley, C. O. and Rathmacher, R. P. 1984. Effect of monensin on ruminal fermentation in vitro and in vivo. Journal of Animal Science 58:194-202.

Russell, J. B. 2002. Rumen microbiology and its role in ruminant nutrition. James B. Russell ${ }^{\circ}$, Ithaca.

Sugiura, N. 1978. Further analysis of the data by Akaike's Information Criterion and the finite corrections. Communications in Statistics, Theory and Methods A7:13-26.

Tamminga, S.; Van Vuuren, A. M. and Van Der Koelen, C. J. 1990. Ruminal behavior of structural carbohydrates and crude protein from concentrate ingredients in dairy cows. Netherlands Journal of Agricultural Science 38:513-526

Tempelman, R. J. 2004. Experimental design and statistical methods for classical and bioequivalence hypothesis testing with an application to dairy nutrition studies. Journal of Animal Science 82(E. Suppl.):162-172.

Thiex, N. J.; Manson, H.; Anderson, S. and Persson, J.-À. 2002. Determinantion of crude protein in animal feed, forage, grain, and oilseeds by using block digestion with a copper catalyst and steam distrillation into boric acid: collaborative study. Journal of Official Analytical Chemists 85:309-317.

Thiex, N. J.; Anderson, S. and Gildemeister, B. 2003. Crude, fat, hexanes extraction, in feed, cereal grain, and forage (Randall, Soxtec/Submersion Method): collaborative study. Journal of Official Analytical Chemists 86:899-908.

Udén, P.; Colucci, P. E. and Van Soest, P. J. 1980. Investigation of chromium, cerium and cobalt as markers in digesta. Rate of passage studies. Journal of the Science of Food and Agriculture $31: 625-632$ 
Van Soest, P. J. 1994. Nutritional ecology of the ruminant. 2nd ed. Cornell University Press, Ithaca, USA.

Van Soest, P. J. 1965. Symposium on factors influencing voluntary intake of herbage by ruminants - voluntary intake in relation to chemical composition and digestibility. Journal of Animal Science 24:834-843.

Vieira, R. A. M.; Tedeschi, L. O. and Cannas, A. 2008a. A generalized compartmental model to estimate the fibre mass in the ruminoreticulum: 1. Estimating parameters of digestion. Journal Theoretical Biology 255:345-356.
Vieira, R. A. M.; Tedeschi, L. O. and Cannas, A. 2008b. A generalized compartmental model to estimate the fibre mass in the ruminoreticulum: 2. Integrating digestion and passage. Journal Theoretical Biology 255:357-368.

Vieira, R. A. M.; Campos, P. R. S. S.; Coelho da Silva, J. F.; Tedeschi, L. O. and Tamy, W. P. 2012. Heterogeneity of the digestible insoluble fiber of selected forages in situ. Animal Feed Science and Technology 171:154-166.

Waldo, D. R.; Smith, L. W. and Cox, E. L. 1972. Model of cellulose disappearance from the rumen. Journal of Dairy Science 55:125-129. 